\title{
An Exploration into the Functions of College Music Education in Social Participation in Contemporary China
}

\author{
Yuying Tian \\ Youth League \\ Hebei Finance University \\ Baoding, China
}

\author{
Jiannan Jia \\ Business English Department \\ Hebei Finance University \\ Baoding, China
}

\begin{abstract}
Recently, the education for all-around development has been greatly emphasized in China. This thesis focuses on one of its important aspects, i.e. music education at colleges. It first presents the historical development of Chinese college music education, and then mainly discusses the functions of music education in social participation in contemporary times, which involved the relationship between music education and music production, music communication, music popularization and music audience.
\end{abstract}

Keywords—all-around education; college music education; functions in social participation

\section{BACKGROUND}

Along with the accelerating development of economic globalization and cultural plurality, the role of public education has become more and more prominent. Whether a state can take up a leading position in global competition largely depends on its education and the quantity and quality of its talents. Since the reform and opening-up policy was introduced in 1978, great achievements have been made in China's education. In new situations and under new circumstances in the $21^{\text {st }}$ century, the Chinese government has proposed the new concept of education which places more emphasis on humanistic spirit and individual value. A series of policies were formulated and adopted for this purpose. In June 1999, the State Council made the decision to carry out a comprehensive reform on education for allaround development of talents. As an important part of education, the status of art education was also raised. In July 2002, Standards on School Art Education was issued by the Ministry of Education.

\section{THE IMPORTANCE OF MUSIC EDUCATION AT COLLEGES}

The dominant concept of education in China now is to cultivate all-around talents, which is mainly achieved by arts education. Colleges are the major institutions where this idea is put into practice. It concerns the physical and mental health of college students and helps them to fully develop their talents and personality.

Music education for college students is one of the effective ways to achieve all-around education, as the
Standards on School Art Education specifies "Art classes are an integral part in college education and play a decisive role in cultivating all-around talents." Among art classes, music education is a vital aspect. Music education for college students is attached great importance at present and a variety of activities are organized each year. It is aimed at cultivating their keen perception of art, developing their aesthetic appreciation, improving their moral behaviors, promoting their mental health and purifying their souls. Therefore, the teaching methods are not limited to skills instruction or music appreciation, but more importantly, it demands more diverse and perceptional ways of teaching to convey positive life values, work ethics, patriotism etc. In this way, teachers are expected to reconsider the status, roles, functions and significance of music education for students in contemporary times by reflecting on its historical development. They also need to clarify the main objectives of music classes at colleges and develop its curriculum in an appropriate way.

\section{The Historical Development of Music EDUCATION AT COLLEGES}

Music education for college students has long had a difficult time in China. It was gradually formed, developed and standardized. This paper mainly focuses on two main stages: one is the stage from the outbreak of the Opium War in 1840 to the beginning of the May 4th Movement in 1919, the other is from the end of May 4th Movement in 1919 to the founding of People's Republic of China (PRC). The period after the founding of PRC also belongs to contemporary times, so the historical development of music education in this period is briefly introduced as well for full explanation.

Since the outbreak of the Opium War in 1840, Western countries influenced China's politics, economy, culture and religion by means of privileges obtained through unequal treaties. Chinese civilians of all ranks and classes began to call for drastic reforms in every social aspect of life, which to some extent promotes the birth of music education in China. For example, some officials who advocated the westernization movement and intellectuals like Zhang Zhidong and Liang Qichao formed new cognitions on the significance of music education. They actively offered 
singing courses in schools and spread new songs containing reformist messages to civilians. Liang Qichao mentioned in his work, "Education on poetry and music is one of the priorities to enhance the quality of Chinese citizens." During this period, under the great influence of Western religions and culture, music education began to flourish at schools and a collection of original songs were passed on. It was first in church schools that music classes were offered by Western missionaries, for example, Hong Kong Morrison School in 1842, Shanghai Xuhui Public School in 1850, Shanghai Qingxin Female Private School in 1861. Other music-related classes or groups like Dengzhou Academy music classes, the Art Department of Huiwen Academy, Xiaozhan military band in Tianjin and Shimin Academy singing classes were also en vogue. One of the typical examples is Qiushi Academy (later Zhejiang University) which offered a music elective course that was mainly delivered by a Japanese teacher and later by famous artist Feng Zikai. Since 1903, music classes were officially listed as the subject of public schools.

During the period of the May 4th Movement, the development of education, literature and art was aimed at ordinary citizens. Under this backdrop, new academicsoriented music societies and groups were set up, which endeavored to spread Chinese and foreign music knowledge and train members' music skills. Some of them even created publications to make music popular among ordinary citizens and to promote music-related academic development. At that time, music groups in major distinguished universities and institutes of China sprung up and showed a picture of prosperity. In Tsinghua University, the first formal music department was founded in 1931. Peking University also established its research institute on music in 1919. Its director was the principal Cai Yuanpei, who proposed the famous idea that "In order to train music talents, we need to learn from Western music and instruments and at the same time preserve the quintessence of traditional Chinese music". Shanghai Transportation University, Yenching University and Fu Jen Catholic University also created their own music groups. In 1927, Shanghai Public Music College was founded and became the first specialized music education institute.

After May the 5th Movement, according to the new educational system, there were mainly three types of music departments. The first one was for "undergraduates", who had to attend all required courses with desirable grades according to the credit system. The second type was to train future music teachers. In 1930s and 1940s, 10 public normal universities were founded, among which 6 set up a music department. Some provincial normal colleges also had their music departments. The National Conservatory of Music (Qingmuguan, Chongqing) founded in 1940 and the Songlingang Branch of National Conservatory of Music (Chongqing) founded in 1942 had the greatest influence.

Since the founding of the PRC, music education at colleges developed rapidly. In 1956, Beijing Art Normal College was founded and became the first advanced normal school specialized in training art teachers independently. Since then, provincial or municipal art normal colleges were founded gradually. On the other hand, the number of music major pilot programs was more than 40 in 1981 and then increased to around 100 in 1988 and up to 290 in 2005. Since reforms and opening-ups, music education in China has been promoted in a more diverse, flexible and open way. Specialized music departments were set up in major art academies at universities and colleges. They published school journals and set up research institutes to promote the work of music education and research. In early 1980s, main music institutes like "Social Conservatory of Music" (1981) and "China's Correspondence Conservatory of Music" (1985) were founded and led the trend of music education for part-time students in order to promote the functions of college music education in social participation.

\section{Functions of College Music Education in SOCIAL PARTICIPATION}

Music, as one of the important aspects of artistic and cultural activities, is also a crucial way to convey human feelings and emotions. Music education at universities and colleges has been a remarkable chapter in the historical book of contemporary music development. The process of music instruction and research and mutual communication between teachers and students is, in essence, a process where they produce music and participate in social interaction through music. By introducing the historical development of music education at colleges in China, it has been found out that the role of music in social participation has a long tradition, a solid foundation and great vigor. This thesis mainly concentrates on the relationship between music education at colleges and the following four aspects: music production, music communication, music popularization, and music audience.

\section{A. Music Education at Colleges and Music Production}

Music production refers to the behavioral process of composing and producing music. Its fundamental features are as follows. The production of music is in accordance with the mental needs of general public in contemporary times; it is full of imagination and creativity; it is not for the purpose of transacting and making profits. On the other hand, the objective of music education at colleges is consistently to develop skilled profession-oriented talents with music perception and appreciation ability. In this way, music education for college students has become a form of music production. The process of music production is fundamentally interlinked and intertwined with music education at colleges.

\section{B. Music Education at Colleges and Music Communication}

Music communication, or music spread, is the prerequisite for making certain music popular. It produces a specific group of listeners and realizes the social functions of music. Music education for college students, on the other hand, is to convey and disseminate messages through the medium of music. This means music education at colleges and music communication are the same in their essences. In the earliest period of music education for college students in China, the majority of musical works and products used to 
be spread at colleges or other institutes, e.g. the Music Research Institute of Peking University. Music communication at colleges satisfies the needs of college students for music appreciation and helps to realize the roles of music in social participation. Besides, the spread of music on campus can be a dynamic source of inspiration for music education for college students since music is a form of art that calls for constant innovation.

\section{Music Education at Colleges and Music Popularization}

The popularization of music refers to the enthusiasm of a certain group of people in society for certain music when they are motivated by certain psychological factors. They keep being passionate for and even crazy over the music as fans and make the music become popular. In particular, college youngsters are the group of people that can easily find empathy in music and desire to study music with interest. Thus, music education for college students can be considered as the process to observe and study the phenomenon of music popularization. In return, the popularization of certain music can also exert a huge influence on college students. Early in the history of China, the famous Chinese song "A Valediction" was made popular and has been passed on from generation to generation on campus. It even has continuous influence on the establishment of music academies and conservatories.

\section{Music Education at Colleges and Music Audience}

One of the objectives of music education at colleges is to impart musical knowledge and train musical skills for the benefit of their artistic sensibility and aesthetic exploration. Specifically, students are expected to form their own insight and appreciation for music, to perform well in music-related activities, and develop a creative ability in music works. In the early period of contemporary China, as the communicational technology lagged far behind the other nations, a large number of music lovers and fans participated in the music education at colleges and formed the major audience of music in society. At present, college students still take up a large percent of music lovers and fans.

\section{CONCLUSION}

China is currently experiencing a dramatic reform of education with Chinese characteristics full of vitality. It calls for the overall development of all-around talents in order to lay a solid foundation for reinvigorating the country through science and education. Music education at colleges, without doubt, plays an indispensible role in the overall development of all-around talent education. Under the background of deepening educational reforms in China, it is expected that the education of music at colleges can be promoted with vigor and vitality.

Throughout the history of music in modern and contemporary China, the music curriculum at colleges has experienced rise and fall for more than a hundred years. Even if the college music education only takes up a small portion of the whole art education, it has a significant influence on the Chinese society. Music education at colleges is expected to produce fine artistic works, develop millions of music talents and boost the prosperity of music development. This paper is a preliminary trial to explore the functions of college music education in social participation. It helps deepen the understanding of music education at colleges in China and provides supplementary information for research in college music education. It is hoped to provide inspiration and enlightenment for future studies in this field.

\section{REFERENCES}

[1] Dingcheng Dai, A Vision of Music Education. Shanaghai: East China Normal University Press, 2001.

[2] Suijin Zeng, Music Sociology. Shanghai: Shanghai Conservatory of Music Press, 2004.

[3] Editorial Staff of Music Research Institute, Chinese National Academy of Arts, A Dictionary of Chinese Music. Beijing: People's Music Publishing House, 1984. 